\title{
THE CORROBORATION RULE AND CRIMES ACCOMPANYING A RAPE
}

Prosecutions for rape require a critical evaluation of the complaining witness's credibility. ${ }^{1}$ The accusation is "easily to be made and hard to be proved, and harder to be defended . . ."; ${ }^{2}$ the penalties are severe $;^{3}$ and judge and jury are often sympathetic towards the prosecutrix and prejudiced against the defendant. To avoid unjust convictions, many states have adopted a rule that a rape conviction cannot be sustained solely upon the testimony of the complaining witness ${ }^{4}$ without some extrinsic corroborating evidence. Whether the corroboration requirement applies to a prosecutrix's allegation of other offenses committed by the rapist in the process of his attack has presented the courts with serious conceptual problems.

Israel Moore allegedly managed to remove a coin purse from the person of his victim while he was in the very process of ravishing her. ${ }^{5}$ $\mathrm{He}$ was prosecuted by the People of New York and convicted of attempted rape, robbery, and grand larceny. ${ }^{6}$ On appeal, the intermediate

1 People v. Radunovic, 21 N.Y.2d 186, 190, 234 N.E.2d 212, 214, 287 N.Y.S.2d 33, 36 (1967) (Breitel, J., concurring); see 3 J. WIGMORE, EvIDENCE § 924a (3d ed. 1940) [hereinafter cited as WIGMORE] ; Juviler, P sychiatric Opinions as to Credibility of Witnesses: A Suggested Approach, 48 CALIF. L. REv. 648, 673-76 (1960) [hereinafter cited as Psychiatric Opinions].

21 M. Hale, Pleas of the Crown * 635 .

3 E.g., Ala. Code tit. 14, $\$ 395$ (1966) (death or imprisonment for a minimum of 10 years at the jury's discretion); IowA CODE ANN. $\$ 698.1$ (1950) (5 years to life imprisonment); N.Y. PENAL LAW $\$ \$ 70.00,130.35$ (McKinney 1967) (discretion of court, up to 25 years imprisonment) ; PA. STAT. ANN. tit. 19, \$1166 (1964) (discretion of court, imprisonment from one day to life).

4 For a thorough compilation of relevant statutory and judicially created corroboration requirements, see 7 WIGMORE \$2061; Note, Corroborating Charges of Rape, 67 CoLUM. L. Rev. 1137, n.3 (1967) [hereinafter cited as Corroborating Charges of Rape]. See also Model PeNal Code $\$ 213.6(6)$ (Proposed Official Draft 1962) providing:

No person shall be convicted of any felony under this Article [including rape and other sex offenses] upon the uncorroborated testimony of the alleged victim. Corroboration may be circumstantial. In any prosecution before a jury for an offense under this Article, the jury shall be instructed to evaluate the testimony of a victim or complaining witness with special care in view of the emotional involvement of the witness and the difficulty of determining the truth with respect to alleged sexual activities carried out in private.

5 The complaining witness testified that the driver of the taxi in which she was a passenger drove into a vacant service station and demanded the witness submit to sexual relations with him. When she refused, he threatened her life, twisted her arm and pushed her into the back seat of the cab. In the process of the attack, the defendant removed a small change purse from her brassiere and threw the purse under the front seat of the cab. After allegedly consummating the rape, defendant returned the prosecutrix's keys but on demand contended he did not have her money. The complainant noted the license number of the cab and later identified Israel Moore as her attacker. Brief for Appellant at 2-5, Brief for Respondent at 2-5, People v. Moore, 23 N.Y.2d 565, 245 N.E.2d 710, 297 N.Y.S.2d 944, cert. denied, 394 U.S. 1006 (1969).

6 Although the prosecutrix's testimony alleged a consummated rape, Moore was never charged with that offense, perhaps because the prosecutor realized that without corroboration of her story, a rape count would never reach the jury. See text accompanying notes $18-24$ infra. 
appellate court reversed the attempted rape conviction and ordered a new trial on that offense, but affirmed the larceny and robbery convictions. $^{7}$ Moore appealed to the state's highest court, contending, inter alia, that his robbery and larceny convictions could not be sustained upon the same uncorroborated testimony which showed a consummated rape. $^{8}$ In People v. Moore, ${ }^{9}$ New York's Court of Appeals affirmed Moore's robbery and larceny convictions ${ }^{10}$ which were based upon this uncorroborated testimony. The court reasoned that because those crimes were not "intrinsically related to rape or committed in aid of effecting rape" the state statute requiring corroboration of the female complainant's accusations did not apply to them. Unfortunately, this rationale fails to clarify this muddled area of the law, and may well aggravate the difficulties in applying New York's corroboration rule strictly in the trial of multiple offenses involving an unsupported rape accusation. It is submitted that People $v$. Moore erroneously reinterpreted the court's own precedents and, more importantly, failed to implement the purposes underlying the statutory corroboration rule.

\section{The Corroboration Requirement}

\section{A. Policies Underlying Adoption of a Corroboration Rule}

The crime of rape raises peculiar evidentiary problems. Rarely do rapists leave behind anything which would substantiate the testimony of the women they attack. "The nature of the crime is such . . . that eyewitnesses seldom are available." I1 Consequently the prosecution of the crime often results in a deadlock between the uncorroborated accusation of the female complainant and the insistent denial of the alleged ravisher.

7 People v. Moore, 29 App. Div. 2d 570, 286 N.Y.S.2d 296 (1967). The memorandum opinion affirmed the larceny and robbery convictions without discussion. The attempted rape conviction was reversed because the People's case lacked corroboration of the complaining witness's testimony. See text accompanying notes 18-24 infra; People v. English, 16 N.Y.2d 719, 209 N.E.2d 722, 262 N.Y.S.2d 104 (1965); People v. LoVerde, 7 N.Y.2d 114, 164 N.E.2d 102, 195 N.Y.S.2d 835 (1959).

8 Defendant argued in the alternative that the state had failed to prove the specific intent required to sustain the larceny or robbery conviction:

None of the actions of the appellant manifested such a felonious intent.

In allegedly removing the purse from [his victim's] brassiere while allegedly defiling her person and throwing it on the floor, the appellant could not be said to have appropriated the purse with the intention of keeping it wrongfully. According to the over-all testimony of [the witness], the appellant was completely preoccupied with repulsing her attempts to ward him off and with struggling to achieve a consummated rape of her.

Brief for Appellant at 10, People v. Moore, 23 N.Y.2d 565, 245 N.E.2d 710, 297 N.Y.S.2d 944, cert. denied, 394 U.S. 1006 (1969). (1969).

9 23 N.Y.2d 565, 245 N.E.2d 710, 297 N.Y.S.2d 944, cert. denied, 394 U.S. 1006

10 Israel Moore is currently serving concurrent sentences of 5 to 10 years for larceny in the first degree and 10 to 30 years for robbery in the first degree. Brief for Appellant at 3, People v. Moore, 23 N.Y.2d 565, 245 N.E.2d 710, 297 N.Y.S.2d 944, cert. denied, 394 U.S. 1006 (1969).

11 Stapleman v. State, 150 Neb. 460, 464, 34 N.W.2d 907, 910 (1948). 
When such a deadlock occurs in other criminal prosecutions, the presumption of the defendant's innocence assures acquittal. But in rape cases, normal operation of that presumption is seriously impaired. The incidence of false accusations and the potential for unjust convictions are perhaps greatest with sexual offenses. ${ }^{12}$ Women often falsely accuse men of sexual attacks to extort money, to force marriage, to satisfy a childish desire for notoriety, or to attain personal revenge. Their motives include hatred, a sense of shame after consenting to illicit intercourse, especially when pregnancy results, and delusion. ${ }^{13}$ In cases of delusion, the woman may describe the attack in remarkably convincing detail, for she herself believes her story but fails to appreciate the significance and consequences of the accusation. "Most women," according to a prominent psychiatrist, "entertain more or less consciously at one time or another fleeting fantasies or fears that they are being or will be attacked by a man. Of course, the normal woman who has such a fantasy does not confuse it with reality, but it is . . . easy for . . . neurotic individuals to translate their fantasies into actual beliefs and memory falsifications . . . ."14 These neurotic individuals can often deceive the most astute judges and jurors into believing that the imagined attack actually occurred.

Under other circumstances, the jury may be relied upon to determine the veracity of the complaining witness. But too often in rape cases the adversary proceeding will offer the jury the opportunity to choose between the account of a woman who alleges that she has been grieviousily wronged and that of a man accused of both violence and indecency. In such situations, outrage at the attacker and sympathy for the attacked mean that the jury will seldom be able to make a dispassionate evaluation of the prosecutrix's credibility. The result of this almost inevitable jury bias is to override the presumption of innocence; ${ }^{15}$ the defendant in effect must disprove the accusation.

12 According to what little legislative history can be found, the objective of New York's corroboration statute is "to protect against false accusations and to prevent

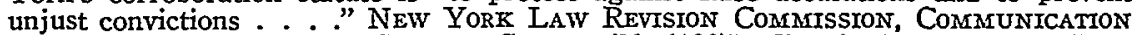
and Study Relating to Sexual Crimes 76 (1937) [hereinafter cited as Law Revision Commission Report]. The report may be found in State of New York, REPORT OF THE LAW Reviston CoMmission FOR 1937, at 401-514.

13 See generally Thomas v. United States, 370 F.2d 621 (9th Cir. 1967) (suggesting the likelihood of false accusation is the only justification for a corroboration rule); Wedmore v. State, 237 Ind. 212, 227, 143 N.E.2d 649, 656 (1957) (dissenting opinion); People v. Smallwood, 306 Mich. 49, 10 N.W.2d 303 (1943); Note, Forcible and Statutory Rape: An Exploration of the Operation and Objectives of the Consent Standard, 62 YALE L.J. 55, 68-70 (1952).

14 Dr. Karl A. Menninger, quoted in 3 WIGMoRe $\$ 924 a$, at 464; see Psychiatric Opinions, supra note 1 , at 674 n.159.

15 In Roberts v. State, 106 Neb. 362, 367, 183 N.W. 555, 557 (1921), the court noted: "Public sentiment seems inclined to believe a man guilty of any illicit sexual offense he may be charged with ..." See Corroborating Charges of Rape, supra note 4 , at 1138 . 
Additionally, the rape accusation is peculiarly difficult to disprove. ${ }^{16}$ Unless the accused can prove he was not with the victim when the crime allegedly occurred, the very lack of evidence corroborating the complainant's accusation deprives the accused of evidentiary means (beyond his own testimony) to establish, for example, that penetration was never achieved or that the complainant consented.

To avoid this harsh treatment of the alleged rapist and insure that the presumption of innocence functions properly, a number of states require corroboration of the complaining witness's testimony to sustain conviction. ${ }^{17}$ A corroboration rule requires that certain suspect testimony be supported by a minimum of independent inculpatory evidence, as a matter of law, before a jury may consider whether the testimony is sufficient to warrant a guilty verdict. ${ }^{18}$

New York has long had a statutory corroboration rule to protect defendants in rape trials. Until recently, it provided that "[n]o conviction can be had for rape or defilement upon the testimony of the female defiled, unsupported by other evidence." 19 In 1967 the state's revised Penal Law explicitly extended the corroboration requirement to include attempts:

A person shall not be convicted of any offense defined in this article, or of any attempt to commit the same, solely on the uncorroborated testimony of the alleged victim . . . . ${ }^{20}$

This amendment has not yet had significant effect on the case law interpreting the corroboration requirement. ${ }^{21}$

16 See Corroborating Charges of Rape, supra note 4, at 1138.

At common law the testimony of the female complainant who charged the commission of a sexual offense was sufficient to uphold a conviction, though her testimony was uncorroborated. People v. Gibson, 301 N.Y. 244, 93 N.E.2d 827 (1950); 7 WIGMORE $\$ 2061$.

17 Note 4 supra. New York provides the basis of this discussion because it is the only jurisdiction which has a sufficient number of cases construing and applying a statutory corroboration rule to make examination profitable. The problems discussed, however, are not peculiar to New York, nor to a statutory corroboration rule, but are characteristic of problems encountered in any jurisdiction attempting to apply a corroboration rule as the critical test of the veracity of the complaining witness.

18 No single definition of corroboration is readily available, for courts and commentators ordinarily interpret only the statutory definition of a particular type of corroboration.

Today corroborative evidence is specifically required by $\mathrm{New}$ York statutes in the following instances: accomplice testimony, N.Y. CODE CRIM. Proc. \&399 (McKinney 1958); extrajudicial confessions, N.Y. Code CrIMr. Proc. $\$ 395$ (MCKinney 1958); guilty pleas before a committing magistrate, N.Y. CODE CRIM. PROC. $\$ 344$ (McKinney 1958); unsworn testimony of minor, N.Y. CODE CrIM. PRoc. \$ 392 (McKinney 1958); and promoting prostitution, N.Y. PENAL LAW \$230.35 (McKinney 1967). Corroboration requirements applicable to the testimony of the prosecutrix in sex crimes of abduction, compulsory marriage, and seduction were omitted when these substantive crimes were deleted from the revised Penal Law.

19 Ch. 88, \$2013, 1909 N.Y. Consol. Laws 2604 (repealed 1967) (emphasis added).

20 N.Y. PENAL LaW $\$ 130.15$ (McKinney 1967). The defined offenses include rape in the first, second, and third degrees. See N.Y. PENaL LAW $\$ \$ 130.25, .30, .35$ (McKinney 1967).

21 Because the facts of Moore took place two years before the revised Penal Law became effective, old $\$ 2013$ provided the applicable corroboration rule. 


\section{B. Implementation of the Corroboration Rule}

New York courts construe the "other evidence" requirement as a demand that corroborative evidence support the complaining witness's testimony as to "every material fact essential to constitute the crime." 22 Corroborative evidence is required to support the prosecutrix's allegations of both the fact of the crime (penetration by force) and the identity of the accused. ${ }^{23}$ This "other evidence" need not be "sufficient in itself to establish the commission of the crime by the defendant but evidence that tends to establish that the crime was committed by him." 24 The New York courts have never definitively prescribed rules for determining the adequacy of this corroborating evidence. They prefer instead to rule specifically on each evidentiary offering separately in light of the principal purpose of the corroboration rule: to reduce the danger of unjust conviction based on unsupported testimony. ${ }^{25}$ Inconsistency in the rule's application suggests that a trial judge's ruling on the adequacy of corroborative evidence may often reflect his own evaluation of the credibility of the complaining witness. For example, in one case the "other evidence" required may need to be especially inculpatory in order to justify a sufficient inference of guilt to reach the jury, while in another case the "other evidence" accepted may seem to be formalistic and technical even to the point of token satisfaction of the rule. ${ }^{26}$

Because of the nature of sex crimes, it has proven extremely diffcult to secure even circumstantial evidence to satisfy the courts. Consequently, district attorneys have sought ways to circumvent the corroboration requirement. ${ }^{27}$ In 1886 the New York legislature repealed a statute which had read:

No person shall be convicted of an assault with intent to commit a crime, or of any other attempt to commit any offense, when it shall appear that the crime intended or the offense attempted was perpetrated by such person at the time of such assault, or in pursuance of such attempt. ${ }^{28}$

22 People v. Page, 162 N.Y. 272, 274-75, 56 N.E. 750, 751 (1900). See also People v. Yannucci, 283 N.Y. 546, 29 N.E.2d 185 (1940).

23 Compare People v. Masse, 5 N.Y.2d 217, 219, 156 N.E.2d 452, 182 N.Y.S.2d 821, 822 (1959); Franklin v. United States, 330 F.2d 205 (1964) (requiring corroboration of both the fact of the crime and the identity of the perpetrator), with State v. Lahmon, 231 Iowa $448,451,1$ N.W.2d 629,631 (1942) (requiring corroboration of corpus delicti). 24 People v. Haskall, 125 Misc. 628, 629, 210 N.Y.S. 337, 338 (Sup. Ct.), aff'd mem., 215 App. Div. 795, 213 N.Y.S. 878 (4th Dep't 1925).

25 For a discussion of cases attempting to define the nature of evidence providing corroboration, see Corroborating Charges of Rape, supra note 4 , at 1139-41; Note, Corroboration in the New York Criminal Law, 24 BRookLYN L. REv. 324, 332-34 (1958).

26 See People v. Radunovic, 21 N.Y.2d 186, 191, 234 N.E.2d 212, 214, 287 N.Y.S.2d 33, 36-37 (1967) (Breitel, J., concurring) ; 7 WIGMORE \$2061, at 354-55.

27 Corroborating Charges of Rape, supra note 4, at 1143-45; see, e.g., People v. Phillips, 204 App. Div. 112, 197 N.Y.S. 567 (1922), aff'd mem., 235 N.Y. 579, 139 N.E. 742 (1923); People v. Kirwin, 74 N.Y. (67 Hun.) 652, 22 N.Y.S. 160 (Sup. Ct. 1893).

28 Vol. 3, part iv, ch. 1, tit. 7, §36 [1859] N.Y. Rev'd Statutes (repealed 1886). 
Prosecutors interpreted this repeal and the subsequent passage of section $260^{29}$ of the old Penal Law to be an abrogation of the doctrine of merger ${ }^{30}$ in New York. Consequently they concluded that the diffculty of obtaining convictions because of a lack of evidence to corroborate the statement of a complaining witness could be obviated by indicting the alleged rapist for one of the several lesser offenses included in the rape, such as assault with intent to rape, or attempted rape, or even endangering the health and morals of a minor. Conviction for these lesser offenses was much easier to obtain because it required only common law credibility rather than statutory corroboration. ${ }^{31}$ This tactic in effect secured convictions for rape, with lesser punishment, when the prosecutrix's testimony was uncorroborated.

For many years the courts tolerated use of this device and sustained convictions for lesser offenses committed in furtherance of the rape. ${ }^{32}$ Opinions holding that these crimes were distinct and separate from the consummated rape, however, were often confusing and inconsistent. ${ }^{33}$ But in 1959 circumvention of the corroboration rule was curtailed by People v. LoVerde. ${ }^{34}$ The defendant in that case had allegedly committed statutory rape by having intercourse with a minor. Because the minor complainant's testimony was uncorroborated, defendant was acquitted of first degree rape, and a charge of assault with intent to commit rape was dismissed at the close of the People's case; but on the trial court's instructions that no corroboration was necessary to convict of "endangering the health and morals of a minor," defendant was convicted of this lesser offense. The New York Court of Appeals held this instruction to be erroneous. ${ }^{35}$ When a consummated rape was the gravamen of the crimes charged, the corroboration rule protected the defendant who was in effect prosecuted for rape, although charged with the lesser crimes.

29 Ch. 88, $\$ 260$ [1909] N.Y. Consol. Laws 2565 (repealed 1967) provided:

A person may be convicted of an attempt to commit a crime, although it appears on the trial that the crime was consummated, unless the court, in its discretion, discharges the jury and directs the defendant to be tried for the crime itself.

30 The doctrine of merger combines lesser offenses which constitute parts of a more serious crime into the latter crime. See People v. Lo Verde, 7 N.Y.2d 114, 117, 164 N.E.2d 102, 103-04, 195 N.Y.S.2d 835, 838 (1959); R. PerkINS, CRTMINAL LaW 554 (2d ed. 1969).

31 Prosecutors could then contend they were not seeking "a conviction . . for rape or defilement" within the meaning of $\$ 2013$. Text accompanying note 19 sipra.

32 See, e.g., People v. DeGroat, 5 App. Div. 2d 1045, 173 N.Y.S.2d 169 (3d Dep't), aff'd 5 N.Y.2d 947, 156 N.E.2d 921, 183 N.Y.S.2d 565, cert. denied, 368 U.S. 863 (1961) ; see Note, Corroboration in the New York Criminal Law, supra note 25, at 334 , and cases cited therein.

33 Compare People v. Chimino, 270 App. Div. 114, 58 N.Y.S.2d 844 (per curiam), afj'd men., 296 N.Y. 554, 68 N.E.2d 863 (1946), revith People v. Cosad, 253 App. Div. 104, 1 N.Y.S.Sd 132 (1937).

347 N.Y.2d 114, 164 N.E.2d 102, 195 N.Y.S.2d 835 (1959).

$35 I d$. 


\section{Extension of the Corroboration Rule}

\section{A. The Identical Evidence Test}

In the decade since LoVerde, the New York courts have attempted to formulate a test for determining which crimes in a given case are sufficiently related to an alleged rape to require that the statutory corroboration requirement be extended to them. ${ }^{36}$ Impelled toward broad extension by prosecutors' attempts to circumvent the statute, but reluctant to extend the corroboration rule beyond the explicit statutory boundaries of "rape or defilement," the courts have had great difficulty establishing a consistent rule of statutory construction. Apparent flexibility in the rule's application has often reflected only judicial confusion. Occasionally a judge has felt compelled to stretch, bend, or replace one test with another to reach the result he believed justice required in the case before him. ${ }^{37}$ In these circumstances some judges have been re-

36 Lower courts also attempted to limit LoVerde to cases in which proof of a consummated rape was the primary charge in the indictment, thereby permitting conviction for attempted rape or assault with intent to rape even though the prosecutrix testified to a consummated rape. See, e.g., People v. Dixon, 36 Misc. 2d 1068, 234 N.Y.S.2d 415 (Sup. Ct. 1962).

37 See, e.g., People v. Smith, 51 Misc. $2 d$ 866, 274 N.Y.S.2d 221 (Rensselaer County Ct. 1966). The defendant, who allegedly raped the complainant at knife-point, moved to dismiss counts for burglary (breaking and entering with intent to rape) and assault, contending that convictions on these counts could not stand without corroboration. The court denied defendant's motion, relying on an identical evidence test: "[C]ertain accompanying crimes, although separate and distinct from the Rape and not included in it, depend on the Rape for proof of one of their elements [and therefore require corroboration]." Id. at 868, 274 N.Y.S.2d at 224 . But the court interpreted cases requiring corroboration of the prosecutrix's testimony of assault and attempted rape as employing an interdependent crimes analysis:

[Attempted rape and assault] cannot be charged when the testimony evidences a completed act of uncorroborated Rape. The crimes precluded by these decisions, however, are included necessarily in the Rape itself and prosecution of them is prevented, on the apparent rationale, that to hold otherwise would subject a Defendant always to conviction for the included crimes where the corroboration necessary for the consummated Rape was lacking or failed in proof; for proof of any of the included crimes would require only the showing of the consummated Rape charged in the guise of the other crimes in order to succeed in the prosecution of the latter without the necessity of proving corroboration of the Rape, thus thwarting the corroborative provisions of section 2013 of the Penal Law.

Id. at 867,274 N.Y.S.2d at 223. This analysis is discussed at text accompanying notes 38-52 infra.

See also People v. Rea, 50 Misc. 2d 721, 271 N.Y.S.2d 410 (New York City Crim. Ct., Kings County 1966). The defendants were convicted of assaults, even though uncorroborated testimony of consummated rapes had been received. The court refused to extend the corroboration requirement to the assaults because they "were subsequent to the uncorroborated acts of rape; were independent of and not in furtherance of the alleged consummations of the uncorroborated rapes; and were in nowise connected with the alleged rapes except possibly as an attempt to silence the already ravished victim." Id. at 723, 271 N.Y.S.2d at 413 . The court held, however, that the defendants could not be convicted of the assaults committed prior to the uncorroborated consummated rape. People v. Smith apparently has been overruled by People v. Sigismondi, 49 Misc. 2d 1, 266 N.Y.S.2d 724 (Sup. Ct. 1966), aff'd mem., 27 App. Div. 2d 937, 280 N.Y.S.2d 912 (2d Dep't), aff'd, 21 N.Y.2d 186, 234 N.E.2d 212,287 N.Y.S.2d 33 (1967) (testimony regarding felonious possession of knife used to coerce victim's submission to rape held to require corroboration; identical evidence test applied). 
luctant to expose their reasoning in full opinions; thus, cryptic pronouncements have left unclear the exact bases of their decisions. ${ }^{38}$

Despite this confusion, one basic test, designated here the "identical evidence test," has emerged. When a judge asks whether the proof of the other crimes depends upon evidence which is identical with evidence necessary to establish the guilt of the defendant for the alleged rape, he is determining the need for corroboration by the identical evidence test. The Court of Appeals has enunciated this test with increasing clarity, particularly in opinions delivered in the past two years.

In People v. Radunovic, ${ }^{39}$ the defendant's conviction for simple assault was based on the prosecutrix's uncorroborated testimony of a consummated rape. Although the trial court erroneously instructed the jury that simple assault needed no corroboration, the intermediate appellate court found this to be harmless error, holding that there was sufficient medical evidence for corroboration. The Court of Appeals, however, ruled that the conviction could not stand "where the jury has found the defendant guilty of an unrelated crime upon evidence which, if believed, would render the accused guilty of rape or assault with intent to commit rape." 40 The medical evidence was insufficient; it could not corroborate the complainant's identification of her attacker. ${ }^{41}$

The majority of the Court of Appeals did not write an opinion in People v. Young, ${ }^{42}$ but reversed the defendants' convictions solely on the authority of People v. Radunovic. In Young, the defendants accosted the complaining witness on her way home from school, grasped her arms, and forced her to walk with them. When they temporarily released their hold, she fled; but she was again seized, taken into an apartment building, and allegedly raped. On these facts, the court held the initial assault, as part of the entire crime, required corroboration. The case is unique because all the judges on both appellate levels seem to have regarded the identical evidence test as the appropriate test to apply to this factual situation, ${ }^{43}$ although they could not agree on the result of that application. Even Judge Scileppi, ordinarily an outspoken critic of any extension of the corroboration rule beyond its strict statutory bounds, employed the identical evidence test in his dissent: "An examination of the facts . . . demonstrates that the simple assault was perpetrated by the defendants well before the commission of the alleged assault with intent to commit rape and the alleged rape. Proof of the simple assault is not dependent upon the allegation or proof of rape." 44

38 See, e.g., People v. English, 16 N.Y.2d 719, 209 N.E.2d 722, 262 N.Y.S.2d 104 (1965) ; People v. Halpern, 29 App. Div. 2d 949, 289 N.Y.S.2d 130 (2d Dep't 1968).

3921 N.Y.2d 186, 234 N.E.2d 212, 287 N.Y.S.2d 33 (1967).

40 Id. at 189, 234 N.E.2d at 213-14, 287 N.Y.S.2d at 35.

41 Id. at 190, 234 N.E.2d at 214,287 N.Y.S.2d at $35-36$.

4222 N.Y.2d 785, 239 N.E.2d 560, 292 N.Y.S.2d 696 (1968).

4329 App. Div. 2d 618, 285 N.Y.S.2d 730 (4th Dep't 1967).

4422 N.Y.2d at 786, 239 N.E.2d at 561, 292 N.Y.S.2d at 697. 
Justice Marsh's dissent in the Appellate Division, which may have been an alternative basis for the subsequent reversal of the case, was even more explicit:

In accordance with the decisions of the Court of Appeals . . . it would appear clear that the requirements of section 2013 of the Penal Law have application not only to criminal charges other than rape where the facts set forth in the indictment constitute rape, but also to those charges where the People rely on proof of a consummated rape to establish the crime charged, although such completed act is not essential to the crime as charged in the indictment. ${ }^{45}$

Before its decision in the Young case, but after Justice Marsh wrote his dissent, the Court of Appeals succinctly stated the identical evidence test in People v. Lennon: "The requirement of corroboration under section 2013 of the former Penal Law, extends only to those charges which are based solely upon evidence which, if believed, would render the accused guilty of the crime of rape." 46

Complex factual situations, however, resist neat compartmentalization. Although individual judges may interpret factual situations in different ways, they may reach the same result by employing different tests. The disposition of People v. English, ${ }^{47}$ for example, can be reached by using at least two different tests.

Leo English first obliged a girl to accompany him to his room, where he robbed her at knife-point. ${ }^{48} \mathrm{He}$ began making sexual advances, but was rebuffed. Subsequently, his amorous endeavors were interrupted by the demands of an importune building superintendent for overdue rent. To avoid further interruption, English compelled the girl to go with him to the top floor of another apartment building. He there directed her to the top of the staircase leading to the roof and, with knife still in hand, demanded more money. When she replied she had no more, he ordered her out onto the roof and twice raped her. Upon her uncorroborated testimony English was convicted of robbery, grand larceny, assault with intent to rape, and attempted rape. The Appellate Division affirmed all four convictions without opinion. ${ }^{49}$ The

4529 App. Div. 2d at 619, 285 N.Y.S.2d at 733 (citations omitted).

4622 N.Y.2d 677, 678, 238 N.E.2d 756, 757, 291 N.Y.S.2d 369, 370 (1968).

4716 N.Y.2d 719, 209 N.E.2d 722, 262 N.Y.S.2d 104 (1965), modifying mem. 22 App. Div. 2d 1016, 255 N.Y.S.2d 1019 (1964) (mem.), noted in 32 BRookLYN L. REv. 434 (1966). People v. English is of primary importance because it rejected the restrictive reading of LoVerde which enabled prosecutors to obtain convictions for attempted rape or assault upon the victim's uncorroborated testimony by not joining these counts with a charge of consummated rape. The English holding extends the LoVerde rationale, requiring corroboration of any lesser crimes where the gravamen of the acts alleged is a consummated rape.

48 The facts are drawn from People v. Sigismondi, 49 Misc. $2 d 1,6,266$ N.Y.S.2d 724, 729 (Sup. Ct. 1966).

4922 App. Div. $2 d$ 1016, 255 N.Y.S.2d 1019 (2d Dep't 1964) (mem.). 
Court of Appeals, however, reversed the convictions for attempted rape and assault with intent to rape "on the ground of a lack of the corroboration required by law for such convictions when testimony as to an actual rape has been received ...." 50 The robbery and larceny convictions were affirmed without discussion.

\section{B. The Interdependent Crimes Test}

The Court of Appeals failed to indicate what test it employed in English to distinguish the complainant's allegations of assault and attempted rape (corroboration required) from her allegations of larceny and robbery (no corroboration required). Although in all later decisions English has been cited to support the identical evidence test, ${ }^{\text {,1 }}$ the majority in People v. Moore cited it in support of their new test, designated here the "interdependent crimes test." This test may be stated as follows: where the other crimes charged furthered or aided an attack culminating in a consummated rape, the complainant's testimony must be corroborated to sustain convictions for those other crimes. ${ }^{22}$ Applying either test to the facts of English would produce the same result. The assault and attempted rape, as opposed to the robbery and larceny, were "interdependent" crimes; they were committed to effect the consummated rape. Under the identical evidence rationale, the body of evidence necessary to prove the assault and attempted rape also contained elements necessary to prove the rape, while the robbery and larceny could be proved independently of that evidence. Despite this identity of result in such circumstances, the Court of Appeals seems to have felt the unusual factual situation in Moore warranted a departure from precedent, and the employment of a new test.

Israel Moore committed the same crimes Leo English committed, but Moore altered the time sequence. He committed his crimes concurrently; English had allowed at least thirty minutes to elapse between the robbery and the rape. ${ }^{53}$ This distinction between Moore and English or other combination robbery-rape cases underlies in part the difference between the majority and dissent in Moore. The majority, speaking through Judge Bergan, declared this distinction to be of no conse-

50 16 N.Y.2d 719, 720, 209 N.E.2d 722, 722, 262 N.Y.S.2d 104, 105 (1965).

51 See, e.g., People v. Young, 22 N.Y.2d 785, 239 N.E.2d 560, 292 N.Y.S.2d 696 (1968) (mem.); People v. Lennon, 22 N.Y.2d 677, 238 N.E.2d 756, 291 N.Y.S.2d 369 (1968) (per curiam); People v. Jenkins, 22 N..Y.2d 675, 238 N.E.2d 755, 291 N.Y.S.2d 368 (1968), aff'g per curiam 28 App. Div. 2d 1097, 284 N.Y.S.2d 302 (1967); People v. Radunovic, 21 N.Y.2d 186, 234 N.E.2d 212, 287 N.Y.S.2d 33 (1967).

52 The court in People v. Moore concluded that "the extension [of the corroboration rule] has been directed in each case to crimes intrinsically related to rape or committed in aid of effecting rape." 23 N.Y.2d 565, 567, 245 N.E.2d 710, 297 N.Y.S.2d 944, 945 (1969). The label of "interdependent crimes test" used here is derived from Moore's explanation of the application of the corroboration rule in Radnunovic: "[A] ssault charges were based on acts each interdependent upon the rape itself." Id. at 568, 245 N.E.2d at 710, 297 N.Y.S.2d at 946 (emphasis supplied).

5332 Brooklyn L. Rev. 434, 435 n.4 (1966). 
quence, because the interdependent crimes test had already determined for them that the robbery and grand larceny convictions must be affirmed. Neither the robbery nor the larceny was committed in furtherance of the consummated rape; therefore, they were not interdependent crimes and testimony concerning them required no corroboration. .4 Despite his distaste for the "unsatisfactory corroboration rule," 55 Judge Breitel emphasized in dissent that Court of Appeals precedents required the use of the identical evidence test under which the simultaneity of the crimes demanded reversal.

Complainant's testimony that defendant had removed a change purse from her person while he was raping her was the only evidence to support the larceny and robbery charges. This testimony was inseparable, by reason of the unity of time, place, and circumstances, from that which would also render the accused guilty of rape. Nor was there proof of the elements embraced in the other or lesser crimes charged other than the testimony which required corroboration. Hence, the lack of corroboration requires reversal of the robbery and larceny convictions . . . . Thus, in the Lennon case it was said: "The testimony of the complaining witness as to the consummated rape, though relevant, was not a necessary element to support the defendant's conviction on the charge of robbery in the first degree. The requirement of corroboration, under section 2013 of the former Penal Law, extends only to those charges which are based solely upon evidence which, if believed, would render the accused guilty of the crime of rape." 56

The Moore result, then, turned on the test applied. Because of the simultaneity of Moore's crimes no testimony could support the allegation of robbery other than testimony concerning the consummated rape. Consequently, in order to sustain Moore's convictions, the majority had to substitute its interdependent crimes test for the identical evidence test. To justify this substitution, the majority reinterpreted decisions which had relied upon the identical evidence test, declaring that those decisions had really used the interdependent crimes test. The court may have considered this reinterpretation legitimate because of the fortuitous circumstance that application of either test will yield the same result in a majority of cases. Yet the endorsement of the interdependent crimes test does not provide a more satisfactory explanation of which crimes require corroboration than the identical evidence test.

5423 N.Y.2d 565, 567, 245 N.E.2d 710, 711, 297 N.Y.S.2d 944, 945 (1969).

55 Id. at 568, 235 N.E.2d at 711, 297 N.Y.S.2d at 946.

$56 I d$. at 568-69, 235 N.E.2d at 711, 297 N.Y.S.2d at 946-47, (quoting People v. Lennon, 22 N.Y.2d 677, 678, 238 N.E.2d 756, 757, 291 N.Y.S.2d 369, 370 (1968)). 
Not only did the Moore decision fail to clarify when the corroboration rule must be applied to certain accompanying crimes, it also has tended to confuse New York's lower courts in subsequent application of the corroboration rule. For example, an intermediate appellate court found that recent precedents-especially Moore-and the new Penal Law's extended corroboration requirement required a reevaluation of all the corroboration rule cases since LoV erde..$^{57}$ A few months earlier, the same court ignored Moore's interdependent crimes test and ruled on the basis of older, identical evidence test precedents. ${ }^{58}$ This confusion is predictable, since Moore can be read as setting forth a special test for the simultaneous crimes situation, or as suggesting that the identical evidence test and interdependent crimes test are really interchangeable, or as indicating the identical evidence test is to be displaced altogether by a new test. A fourth possibility is suggested here: that Moore was incorrectly decided in the first instance and should be overruled.

The majority overlooked the fundamental purpose of the statutory corroboration requirement: to give defendants special protection in an area filled with false accusations. ${ }^{59}$ A woman disposed to fabricate an allegation of a sexual attack might easily add to her story accusations of assault, robbery, or other crimes, particularly if she is aware of the need for corroboration. The majority failed to extend the corroboration rule to these additional accusations because it wished to avoid imposing on women what it believed to be an unwarranted testimonial disability. ${ }^{60}$ To realize this latter goal, however, the majority was forced to adopt an untenable position: although a woman's testimony concerning the facts of an alleged consummated rape are too untrustworthy to support a rape conviction, the same uncorroborated testimony will support a conviction for all crimes not "intrinsically related to the rape." 61 What the majority failed to recognize is that the imposition of a testimonial disability is the core of the corroboration requirement; such a disability is the only protection the defendant has against the judge and jury's susceptibility to prejudice.

The Moore court did not assign sufficient importance to the danger that a jury might convict the defendant of crimes tried with the rape accusation when the jury believes the defendant guilty of the sexual attack but is prevented by the corroboration requirement from return-

57 People v. Doyle, 31 App. Div. 2d 490, 300 N.Y.S.2d 719 (2d Dep't 1969).

88 People v. Scruggs, 31 App. Div. 2d 842, 298 N.Y.S.2d 194 (2d Dep't 1969). Justice Beldock, dissenting, thought People v. Moore governed and dictated the opposite result. Id. at 843, 298 N.Y.S.2d at 196.

59 See note 12 supra \& accompanying text.

60 See People v. Radunovic, 21 N.Y.2d 186, 194, 234 N.E.2d 212, 217, 287 N.Y.S.2d 33, 39-40 (1967) (Bergan, J., dissenting).

61 It has been suggested that the opposite result would provide an incentive for an increase in the number of consummated rapes. Id. at 193, $234 \mathrm{~N}$.E.2d at 216, 287 N.Y.S.2d at 38 (Scileppi, J., dissenting). 
ing a guilty verdict on the rape charge. Regardless of what instructions a jury is given, the jurors will probably assess the credibility of the complainant concerning the rape charge and, if they believe her story, be influenced by the sexual attack in reaching a verdict on the other crimes. Frustrated by their inability to punish the defendant for the serious sexual offense and emotionally prejudiced against him, the jurors might convict on the other crimes even though they did not believe beyond a reasonable doubt that the defendant committed them. The majority in People v. McCullough ${ }^{62}$ expressed this fear. The defendant there was indicted for sodomy, two counts of assault, and endangering the health and morals of a minor, upon the uncorroborated testimony of his fifteen-year-old stepdaughter. The jury convicted the defendant on all counts, but the intermediate appellate court reversed the convictions because, as a matter of law, the uncorroborated allegations should never have reached the jury. The court stated:

[C]onviction of the crime of assault with intent to commit sodomy should also be reversed even though the testimony of the complainant, although not corroborated, was legally sufficient, if credited, to sustain the conviction. Defendant's substantial rights were prejudiced on his trial on the sodomy counts by the introduction of evidence of commission of the crime of rape, which was obviously insufficient to support a conviction of assault with intent to commit that crime; and it is impossible to determine the extent to which the jury was influenced by that evidence in arriving at the conclusion that defendant had committed the crime of assault with intent to commit sodomy. ${ }^{63}$

If the other crimes which allegedly accompanied the consummated rape could be proven without introducing testimony concerning a consummated rape, the case should reach the jury without application of a corroboration requirement. But where an element of any crime allegedly a part of the sexual attack can be made out only by the complainant's testimony concerning facts which also constituted an element of rape, the corroboration requirement must be satisfied before a conviction on the other crime can be sustained. ${ }^{64}$

Finally, Moore's interdependent crimes test in effect allows prosecutors to circumvent the corroboration rule. The circumvention differs

6228 App. Div, 2d 709, 280 N.Y.S.2d 931 (2d Dep't 1967).

63 Id. at 710, 280 N.Y.S.2d at 933.

64 See People v. Scruggs, 31 App. Div. 2d 842, 298 N.Y.S.2d 194 (2d Dep't 1969). The court reversed a conviction for burglary where a common assault was a necessary element for proof of both the burglary and the alleged consummated rape. Given the existence of an assault common to both crimes committed, the case is similar to People $v$. Moore. The difference in results emphasizes the impact of the two tests in determining the need for corroboration. The robbery conviction in Moore depended upon the presence of an element of force and fear, of constructive assault. The Court of 
from that in the LoVerde situation, where the gravamen of the crime charged was rape, for here the crime charged need not be a part of the sexual attack. The prosecution can thus rely upon the jury to become prejudiced after introduction of the complaining witness's uncorroborated testimony, if credible, and to become frustrated after the judge explains the operation of the corroboration requirement. Conviction for the other crimes then will act as an alternative to conviction for the alleged rape to satisfy the jury's desire to punish the offender. The facts of Moore are particularly compelling. The uncorroborated testimony of the prosecutrix that she was forcibly raped indicates that her assailant was too fully occupied with her violent resistance to have formed a specific larcenous intent. ${ }^{65}$ It would require crediting Moore with extraordinary presence of mind and powers of concentration to find him capable of forming such an intent. Affirming a conviction in such circumstances encourages prosecutors to press charges for "intrinsically unrelated" offenses allegedly committed with a rape in the hope that jurors will convict of the unrelated offenses in order to punish the defendant for the alleged rape. Although this practice might result in a crude kind of justice in some cases and remove dangerous individuals from the streets, it cannot be tolerated within a system that purports to consider a man innocent until proven guilty.

\section{CONCLUSION}

The problems raised by the corroboration rule are more fundamental than the judicial confusion which surrounds its application to complex factual situations. They arise primarily when a jurisdiction tries to make its corroboration requirement account for too much. Judge Breitel, a persistent critic of New York's requirement, warns:

It is an immature jurisprudence that places reliance on corroboration, however unreliable the corroboration itself is, and rejects overwhelming [sic] reliable proof because it lacks corroboration, however slight and however technical even to the point of token satisfaction of the rule. Quite often the corroboration supplied under the various rules in criminal law, and particularly in the sex cases, is weak indeed and supplies only a formalistic bridge over a very real and profound discomfort in such cases because of the many motivational or quasi-pathological reasons for distortion of the facts. ${ }^{66}$

Appeals found such force and fear, 23 N.Y.2d at 567, 245 N.E.2d at 710, 297 N.Y.S.2d at 945 . But the assatult is the same assault, the force and fear the same force and fear, as was the necessary element of the alleged consummated rape.

If the crimes allegedly committed by the defendant did not depend upon some common essential element, the prosecution of the nonsexual offense could be separated from the prosecution of the rape to avoid the problem of prejudice.

65 Note 8 supra.

66 People v. Radunovic, 21 N.Y.2d 186, 191, 234 N.E.2d 212, 214, 287 N.Y.S.2d

33, 36-37 (Breitel, J., concurring); see 7 WIGMORE §2061, at 354-55. 
Conceding all this, the corroboration requirement remains the device the legislature has chosen to bridge this "profound discomfort." Moreover, it does provide some check on the prejudices peculiar to prosecutions for rape. Judicial reinstatement of the identical evidence test as the applicable rule of statutory construction would better implement the policies underlying the corroboration requirement as set down by the legislature, and afford greater predictability for future application of the rule to crimes allegedly accompanying a consummated rape. 